Proceeding ICOGISS 2019

Page 9-26. ISBN: 978-602-6 988-75-1

Web Jurnal Online: jurnal.unmuhjember.ac.id

By: Sataporn Roengtam

Citizen Engagement And Local Governance Development

\title{
CITIZEN ENGAGEMENT AND \\ LOCAL GOVERNANCE \\ DEVELOPMENT
}

\section{Sataporn Roengtam}

Department of Public Administration, Faculty of Humanities and

Social Sciences Khon Kaen University, Thailand

sataro@kku.ac.th

\begin{abstract}
:
Citizen engagement can build responsive local governance, usually through gaining increased government attention and responsiveness to issues that might have been previously ignored. The potential of citizen assembly will contribute to concrete development gains, through demands for more responsive local government action. It can strengthen local governance accountability and responsiveness to citizen-led initiatives. Citizen assembly led to other forms of institutionalized practices that in turn strengthen the possibilities of further citizen engagement which citizen has the creation of new institutional mechanisms whereby citizen voice can be expressed to government institutions.

Key Words: Citizen engagement, Local Governance, Citizen Engagement, Civic Education, Area Based Administration
\end{abstract}




\section{INTRODUCTION}

'Citizen Assembly' is an area-based management jointly developed by the public. The main purpose is to use as an which all government agencies, including civil society organizations in and out of the area, can be participate in development at the local level. The goal is to create equitable allocation of resources which is a balance between economic, social, and political development while respecting local wisdom, ways, and cultural traditions. It would create consciousness and raise awareness of community rights for the common good (Gaventa and Barrett 2012).

The development of public participation in local government, in this way, means the local people are able to respond to their problems and needs, more effectively. It is a tool used to express the needs of the people to other sectors, in particular, the government. It contains public sector practice guidelines that are based on data that efficiently reflect the causes of the actual problems in the local community (Hokayem and Kairouz 2015). Citizen assembly aims to create social change on a community foundation through the cooperation among people and the related agencies. All the dimensions of the practice are mainly related to the local development master plan which will allow the local communities the opportunity to jointly define their own future and to create both physical and conceptual changes within the local community.

Citizen assembly focuses on a participatory process involving contributions from both within and outside the community. The assembly members progress to drive development and create self- governance with the changes not only employing troubleshooting activities but also mobilizing development towards structural change. These actions will modify the power relationship between the community and the local agencies, and also those at national level. Under fundamental principles, citizen assembly is created through rules, or an agreement of the community, sharing common values and developing a civic political system within the community.

Prior to, there has been little chance of citizens getting involved in the process of local development policy and planning as most local development policies are the legal duty of the government agencies only. With such restrictions, the result is that local development plans have been set up in accordance the government agencies. Because they lack of comprehensive data and information, unfortunately, these agencies are unable to respond to the real problems and needs of the people. The results are the development regarding to the operations of local government mainly often not being as successful as it should have been. As these local policies and plans are often not linked to the real conditions of the area, it is often impossible to achieve the expected results due toinadequacies in problem solving approaches or lack of required development in the area (Bovaird 2016). These problems can be solved by establishing citizen assembly to strengthen the relationship between government agencies and the public through joint consultative activities and by supporting the people to negotiate with and advise government agencies regarding their important demands Morris-Suzuki and Jeong 2015; Cruz and Marques 2017). It is an activity that gives both sides a greater opportunity to make decisions together, both local government and the people 
can be involved in strengthening mutual understanding. It will also establish greater trust between government agencies and the people (Zavattaro and Sementelli 2015).Citizen assembly can constructively create an information exchange among all the local stakeholders which can help the public agencies to meet public needs and deliver services to the people who really need them, quickly and effectively. It can encourage people to join government agencies while it is important for public agencies to build links and connect with their citizens. This will lead to the development of quality public services (Virtudes 2016).

Citizen assembly is another way of encouraging people to participate in the assigment and management of their own way of life. (Cegarra-Navarro, Garcia-Perez, and Moreno-Cegarra 2014). It is assumed that public participation will influence upon policy outcomes and that the citizen participation concept is based on pulling all the sectors strongly involved in the public policy process together (Cook, Wright, and Andersson 2017). This is the principle concept of inclusiveness. All sectors will have a chance to co-create acceptable and fair decision making. All of them will have been partners through a process of constructive discussions. This concept can be used to design public policies that produce good results for all. (Goetz et al. 2015).

This concept shows respect for diversity in community engagement because it is a concept that drives the general public in the local government administrations in order to take full responsibility for their own way of life. This one would like to encourages people in the community to consider various public issues collectively and to deal with. (Yin, et al. 2016). Engagement of people via citizen assembly is done through social networks because this allows individuals to express their views on the issues they need to be heard. It extends beyond people to other sectors in the locality that play important roles in local government's management process. It can highlight collaborations between the people and local government by including public knowledge to improve the efficiency and effectiveness of public service deliveries. (Wijnhoven, Ehrenhard and Kuhn, 2015).

This study is interested in studying the mechanisms of formulation and the implementation of citizen assembly in Thailand. It aims to study the details and the success of this practice to provide knowledge that can 'fill the gap' in the development of citizen engagement in local government. The results can provide guidelines for promoting citizen engagement in the administration of local government and promote the decentralization process in terms of the concept and practices of local governance. This will result in a structural change which will be able to create efficiency and effectiveness of local development. Finally, it will contribute to the achievements of the local community, both economic and social development. 


\section{THEORY}

A citizens' assembly is a group of citizens who are selected at random from the population. (with stratification) to learn about, deliberate upon, and make recommendations in relation to a particular issue or set of issues. The citizens' assembly model has gained increasing attention in academic literature and has been applied with considerable success in Canada, the Netherlands, and Ireland. Its advocates claim it has a number of notable advantages over other kinds of political processes.

Firstly, by engaging people other than those who choose to put themselves forward for elections or those who choose to attend public meetings, it extends participation in detailed policy discussions beyond very narrow, unrepresentative groups. Secondly, by focusing on people who are not tied to election manifestos or agreed organizational positions, it allows the members to engage freely in discussion and deliberation, in which they can listen to and interrogate the arguments and make up their minds on the basis of what they hear. And thirdly, by providing opportunities for detailed learning and by structuring the discussions to be both deliberative and inclusive, it enhances the likelihood that conclusions are well informed and based on careful consideration of a range of arguments and evidence (Flinders, 2016)

The key objective of citizen assembly is to encourage the community to be involved, from the beginning, in the local administration through a community-based convention so that the needs of the community and local offices can be met. The role of local government, in focusing on being the network coordinator and promoting implementation in the community, defines the pattern of the new relationships (Taylor and Kent 2014). Local governments, community organizations, and stakeholders will have a mutually supportive role. There are various structures of responsibility, from identifying the problem, problem solving design, and evaluation of the impacts of public service provision. This is to achieve efficiency and be most beneficial to the local community (Lindquist, Vincent and Wanna (2013; O’Byrne and Daymon 2015)

Citizen assembly creates new relationships between ordinary people and local government, building relationships through new forms of participation, responsiveness, and responsibility. It may be described as a new form of citizen-to-state engagement and is associated with a new concept that represents the voice of the people in local politics. On the other hand, the meaning of citizen engagement is related to local governance. (Kim, Keane, and Bernard 2015).

This concept is an effort to transform from traditional management of statecentric management. It is an attempt to move the concept of local administration from the perspective of the state, which usually focuses on bureaucratic administration, including the activities of the local government. It is a practical collaboration between local governments, local people, and others. This will lead to sustainable development emphasizing the role of local government in creating incentives for citizens to participate in decision-making and the development of policies and plans for local community development (Cheshire, Everingham, and Lawrence 2014; Hoffken and Streich 2015). The main concept focuses on civic capacity building, practicing negotiation and participation in decision making. It contains basic democratic principles, righteousness, 
transparency, and identifies liability. This is a guideline to help local government officials respond to the needs of local people through the provision of public services which meet their needs and the community's interests. (Korthagen, Iris, and Van Meerkerk 2015).

This concept attempts to promote public policy processes that use a policy-based dialogue to connect across multiple networks. It is a collaborative process between those networks, so there are more actors than just the local government. (Chong et al. 2016). Local governance is an attempt to increase the level of interdependence and interconnectedness among players through the creation of an information exchange network among local government, the people, the private sector, civil society organizations, and non-governmental organizations (D'Ambrosi 2017). Local public groups are organized into a dense network of local community relationships. In order to achieve this, it is important for all parties to coordinate their efforts to develop a consistent local community (Unceta, Castro-spila, and Fronti 2017).

Citizen assembly encourages local governments to focus on working with the people in order to respond to the socio-economic needs of the local community. This will help improve their quality of life and local management will open up the process of planning, policy, and social action by supporting civil society participation in working with local governments systematically (Mayekiso, Taylor and Maphazi, 2013). It offers citizens the opportunity to participate in local decision-making, regarding their own lives, since it will lead to being able to investigate the performance of local government decisions (Men and Tsai 2016).

Citizen assembly may take part in the development of the local development plan either, individually or as a member of a group or organization. The integration of citizens into organizations will strengthen the local community. This community-based organization places great emphasis on encouraging citizens to participate in local development plans at various levels, from the national level down to the local community (Meijer et al. 2017). Organizations are a good tool for empowering citizens to participate in local development plans, and when citizens and communities are well integrated, the so-called citizen assembly will be used as a central area where citizens are given opportunities and community organizations join with the local government to carry out the local development plan to solve the problems facing the local community and society (Roberts 2014). It is like moving citizens from the local level up to the national level, helping to generate social capital that will contribute to strengthening the "Citizen Network" that will be responsible for the public agency's actions in the public interest (Burton 2015).

Citizen assembly respects the human rights of all citizens by recognizing that citizens are dignitaries and have co-ownership of public resources. Together with other citizens in local communities and societies, they have the right to share ideas and to work with the local government to develop public policies that will be used to create public benefits for their local communities. Social benefits are fairly, equally and responsibly distributed to all citizens in a society on the path of democracy. The concept emphasizes on the importance of citizen engagement in every dimension, by proposing that all citizens must be able to link to the operations in the various stages of the process. Citizens co-operate with the state to define the meaning and scope of public interest. 


\section{METHODOLOGY}

The paper proposes that citizen assembly be created with regard to individual involvement in social activities. The underlying theoretical hypothesis is that a combination of sources generates a set of co-productions. We will argue that co-production is best understood as a formation of citizen assembly, embedded in the social relations of the network.

Qualitative methodology will reinforce the results. The purposive province which is the area of study is a province in the Northeast of Thailand. The reason for this choice is due to this province is one of the most successful areas for the implementation of citizen engagement in local development plan in Thailand. Three groups, from each local administration organization, purposively chosen to be key informants, firstly, executive officers, both politicians and bureaucrats, secondly, leaders of council community organizations, thirdly, local leaders such as religious leader, women's leader, leader of civil society community organization and youth organization, etc. Three data collection types were semi-structure interview and focus groups. There are 3 main purposes. Firstly, to identify how citizen assembly can be constructed. Secondly, to explain how citizen assembly is operated. And thirdly, to describe how citizen assembly can make impact. Data analysis was done by applying content and descriptive analysis.

\section{FINDINGS}

1. Making citizen assembly, according to the area of study it was found that the citizen assembly was initiated by the creation of a public forum at community/village level. The members of the sub-district council of the community organizations have been strengthened in their knowledge of the concepts, objectives, goals, and processes and all of these issues, including implementation guidelines, are understandable to all villagers under the concept of self-management provinces.

As the people have enough knowledge and understanding, a forum is open to brainstorm about the issues that will make their villages/communities good to live in. The working group requires the villagers to certify the proposals of each village that will then be presented to the public proclamation process. The resolution to endorse proposals must be approved by at least $60 \%$ of the households. Each proposal will be compiled as a proposal of the village and will be brought to the working group at sub-district level. Considerations will be made for making the proposal at that level.

However, in order to operate in accordance with the plan, a team of trainers would be assigned to support the implementation of the process at village and sub-district level. This function would confirm all stages are followed in the determined process. When the council of community organizations has prepared a forum for hearing from all the villagers, two villagers from each village, together with experts, the mayor, members of the local government council, formal local leaders, and people representing local wisdom become board members. The board would make comments and put forward a final proposal. The proposal would be forwarded to the provincial executive team to compile, analyze, categorize, and prepare a "draft of the citizen charter". This draft would be sent to all sub-districts for a public hearing, with 200 participants invited, including representatives of all government agencies. They join the forum to offer feedback and 
Proceeding ICOGISS 2019

Page 9-26. ISBN: 978-602-6 988-75-1

Web Jurnal Online: jurnal.unmuhjember.ac.id

By: Sataporn Roengtam

Citizen Engagement And Local Governance Development

suggestions before bringing the conclusions of the public hearing to improve and complete the citizen's charter.After the draft of the citizen charter was finished, the community organization organized a public announcement in front of the town hall. People in the province jointly announced their intention to implement the charter. After the announcement, it was used in the development of the province by various government agencies, relevant to the regional and local government organizations. It is now used as a framework for the development of policies, programs, projects and budgetary regulations of these agencies in order to guarantee that the citizen's charter be implemented to achieve the desired goals.

Figure 1 Steps of making citizen assembly

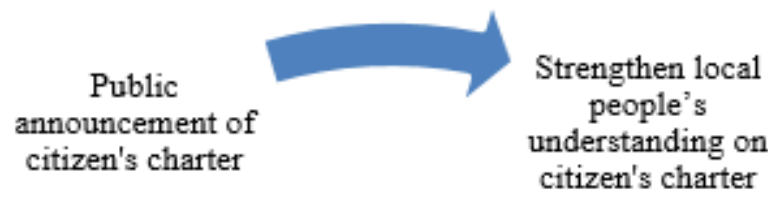

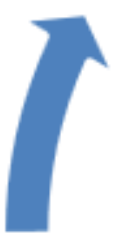

Adjustment for completed citizen's charter
Public deliberated dialogue forums

\& Capacities

building

programs

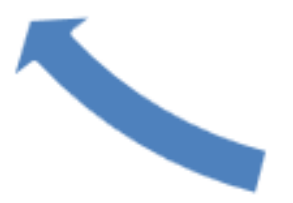

Draft the

charter \&

Public

hearings

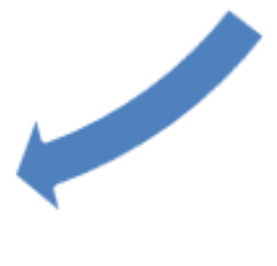


Proceeding ICOGISS 2019

Page 9-26. ISBN: 978-602-6 988-75-1

Web Jurnal Online: jurnal.unmuhjember.ac.id

By: Sataporn Roengtam

Citizen Engagement And Local Governance Development

2. The operations of citizen assembly: after the announcement of the citizen's charter, in order to guarantee that it would be fully implemented according to the goals, citizen assembly had set the process of implementation. This consists of 10 steps of practice displayed by table 1

Table 1 The implementation of citizen's charter

\begin{tabular}{|l|l|}
\hline \multicolumn{1}{|c|}{ Steps } & \multicolumn{1}{|c|}{ A } \\
\hline 1. Create the vision of development plan. & $\begin{array}{l}\text { Brainstorming to set the vision for the } \\
\text { development }\end{array}$ \\
\hline $\begin{array}{l}\text { 2. Organizing a forum to listen to } \\
\text { people's opinions at the village level. }\end{array}$ & $\begin{array}{l}\text { Allowing people to propose their problems and } \\
\text { needs of their local communities }\end{array}$ \\
\hline $\begin{array}{l}\text { 3. Data collection for drafting the } \\
\text { district development plan. }\end{array}$ & Collecting data from the villages \\
\hline 4. Sub-district development planning & $\begin{array}{l}\text { The proposal of all villages will be presented to } \\
\text { the meeting for consideration, analysis, } \\
\text { classification and making to be the sub-district } \\
\text { development plan. }\end{array}$ \\
\hline $\begin{array}{l}\text { 5. The referendum for certification of } \\
\text { the district development plan }\end{array}$ & $\begin{array}{l}\text { The proposals of all villages will be presented to } \\
\text { the meeting for consideration, analysis, } \\
\text { classification, and development to be the sub- } \\
\text { district development plan. }\end{array}$ \\
\hline $\begin{array}{l}\text { 6. The development of community } \\
\text { organizations network }\end{array}$ & $\begin{array}{l}\text { The network will be operated in order to support } \\
\text { participation in multiple issues }\end{array}$ \\
\hline $\begin{array}{l}\text { 7. Drafting of the people's provincial } \\
\text { development plan }\end{array}$ & $\begin{array}{l}\text { Draft the provincial development plan used for } \\
\text { the community forum to hearing the people's } \\
\text { opinions }\end{array}$ \\
\hline $\begin{array}{l}\text { 8. The referendum on the provincial } \\
\text { development plan }\end{array}$ & $\begin{array}{l}\text { Holding a referendum at the sub-district level } \\
\text { administration }\end{array}$ \\
\hline $\begin{array}{l}\text { 9. Submission of the plan to government } \\
\text { agencies in the province }\end{array}$ & $\begin{array}{l}\text { To integrate the people's provincial } \\
\text { development plan into government agencies' } \\
\text { plans or 'One Province One }\end{array}$ \\
\hline $\begin{array}{l}\text { 10. Submission of the plan to the local provinces have to make the plans in } \\
\text { accord with the concept of the provincial } \\
\text { development plan or 'One Local One Plan' } \\
\text { (OLOP) }\end{array}$ \\
\hline
\end{tabular}

3. Impacts of citizen assembly, according to studies, in general, that can be used to increase their autonomy in two ways. First, it can make people more "Confident" in their participation in this process. Second, it can help local people feel they have more "Ownership" of the local community. These two things can bring about a structural 
change in power relations between the people, community organizations, and local government, including government agencies. The implementation of the citizen's charter can open new, effective channels of co working between the people and local organizations. The study concluded that the citizen's charter can empower local people in four aspects as follows.

Firstly, it can empower people's participation in the provincial and local development planning of local government and government agencies by changing the implementation method of the development plan. The result of this change will make people more confident in joining the local

government administrations, after the announcement of the charter. Community Organizations and the people have more opportunities to work with local governments and government agencies. This can

be used to enhance the learning process of the self-administration of local people. It is one of the factors that make the citizen's charter an important part of enhancing the self-governance of the people. The citizen's charter has been constructed in a way that encourages community organizations to participate in the local development plan, together with the government agencies. There are not just plans from the various agencies, or those set up by the policy of central agencies, as in the past. Now the plans and projects must be developed by listening to the needs of the people in the area and they must be approved by the representatives of the people and community organization.

Secondly, it can empower the potential for self-government by the people. According to studies, it has been found that expectations of the use of the citizen's charter is reinforcing people to not just wait for the government agencies in all processes. It is used for promoting people's participation in most of local administrations. It can encourage people to be able to handle their problems and their needs by themselves, as much as possible. Generally, these operations were defined as having only government agencies taking responsibility, to the exclusion of the general public who were unable to contribute. It is limited in terms of resources, administration and law. Therefore, the main goal of citizen assembly is to bring public opinion into practice. It can promote the right of people to work with the local government in codecision making.

Thirdly, the citizen assembly is a process of civic education. It can raise awareness of their rights to participate in the development of the province and their own communities. It has been implemented, as a framework for development plans, at all levels from provincial level to the sub- district level. It is an effective operation to educate people in the best practice of self-government, because it is a process that can encourage people to participate in social learning to manage the development of the planning process. They are trying to bring their self-management approaches into various dimensions.

Fourthly, the results of the implementation of the citizen's charter, according to the above ideas, can contribute to the empowerment of the people through a continuous process of community learning. It can empower people in the community to have knowledge of efficient resource management and it will lead to the realization of their 
own community development experiences. Furthermore, it will lead to the continuous enhancement of the work experience of government agencies and local government organizations and help strengthen the people and community organizations to deal with the problems and issues of the development of their local community. These results can increase the so-called 'self-administration' to be more concrete.

Table 2 Impacts of the citizen assembly

\begin{tabular}{|l|l|l|}
\hline \multicolumn{1}{|c|}{ Impacts } & \multicolumn{1}{|c|}{ Indicato } & \multicolumn{1}{c|}{ Deta } \\
\hline $\begin{array}{l}\text { Empowering people's } \\
\text { participation in provincial and } \\
\text { local development planning }\end{array}$ & $\begin{array}{l}\text { Making people more confident } \\
\text { in joining the local } \\
\text { government administrations }\end{array}$ & $\begin{array}{l}\text { Helping people to offer } \\
\text { their own development } \\
\text { plan } \\
\text { Enhancing the learning } \\
\text { process on self- } \\
\text { administration of local } \\
\text { people }\end{array}$ \\
\hline $\begin{array}{l}\text { Empowering the potential of } \\
\text { people in self-government }\end{array}$ & $\begin{array}{l}\text { Encouraging people to be able } \\
\text { to handle their problems } \\
\text { and their needs by } \\
\text { themselves }\end{array}$ & $\begin{array}{l}\text { Bringing the public } \\
\text { opinion to practice } \\
\text { People have the right to } \\
\text { work with the local } \\
\text { government in co- decision } \\
\text { making }\end{array}$ \\
\hline $\begin{array}{l}\text { Developing continuous civic } \\
\text { education }\end{array}$ & $\begin{array}{l}\text { Awareness of people in their } \\
\text { own community's } \\
\text { development }\end{array}$ & $\begin{array}{l}\text { People participate in co- } \\
\text { managing the development } \\
\text { planning process }\end{array}$ \\
\hline $\begin{array}{l}\text { Empowering people through the } \\
\text { continuous process of } \\
\text { community learning }\end{array}$ & $\begin{array}{l}\text { Realization of their own } \\
\text { community } \\
\text { development } \\
\text { experiences }\end{array}$ & $\begin{array}{l}\text { The enhancement of the } \\
\text { working experience } \\
\text { with government } \\
\text { agencies and local } \\
\text { government } \\
\text { organization, } \\
\text { continuously }\end{array}$ \\
\hline
\end{tabular}

In conclusion, the citizen assembly of this case study has made more changes, in 5 aspects 1. Awakening to join the government in the preparation and management of the developmentplan. After the implementation of the citizen assembly, it has been shown that the number of people, active, and who are interested in participating in the development planning process is increasing. There is also more diversity in groups, no longer clusters of only a few individuals as in the past.

2. Local co-ownership, after the start of using the citizen assembly, there has been a further enhancement of people getting the opportunity to receive various missions due to increased self- management in local government. As a result of local government's 
Proceeding ICOGISS 2019

Page 9-26. ISBN: 978-602-6 988-75-1

Web Jurnal Online: jurnal.unmuhjember.ac.id

By: Sataporn Roengtam

Citizen Engagement And Local Governance Development

acceptance of the citizen's charter for use in local development, it has made people feel that they are responsible for the results of their own local community development. This also gives people a sense of belonging to their local community.

3. Confidence in working with government agencies, after the use of the citizen assembly in the preparation and management of the sub-district and provincial development plan, the people have more faith in joining with the government. This is because the people are able to easily propose a development plan by themselves, in cooperation with the sub-district community organization council at the provincial level and the local government level.

4. The channels for working with government agencies, after the use of the citizen assembly to increase the channels to work with the local government and government agencies, it is now possible to create channels for people to work with the local government and government agencies in the province, more than ever before. These practices reject the often one-way channel of participation at the community stage due to increase in channels for people to submit their plan to be integrated with the local government plan and the provincial development plan of the government agencies.

5. The acceptance by the people of local government and government agencies, after the use of citizen assembly, this study found that the charter can create more acceptance of these agencies. People can anticipatorily submit their proposal to the organizations at all levels. This shows that the citizen's charter can be used as a tool for facilitating acceptance by local government and other government agencies, of the roles of people in local administration.

Figure 2 The results of the citizen assembly

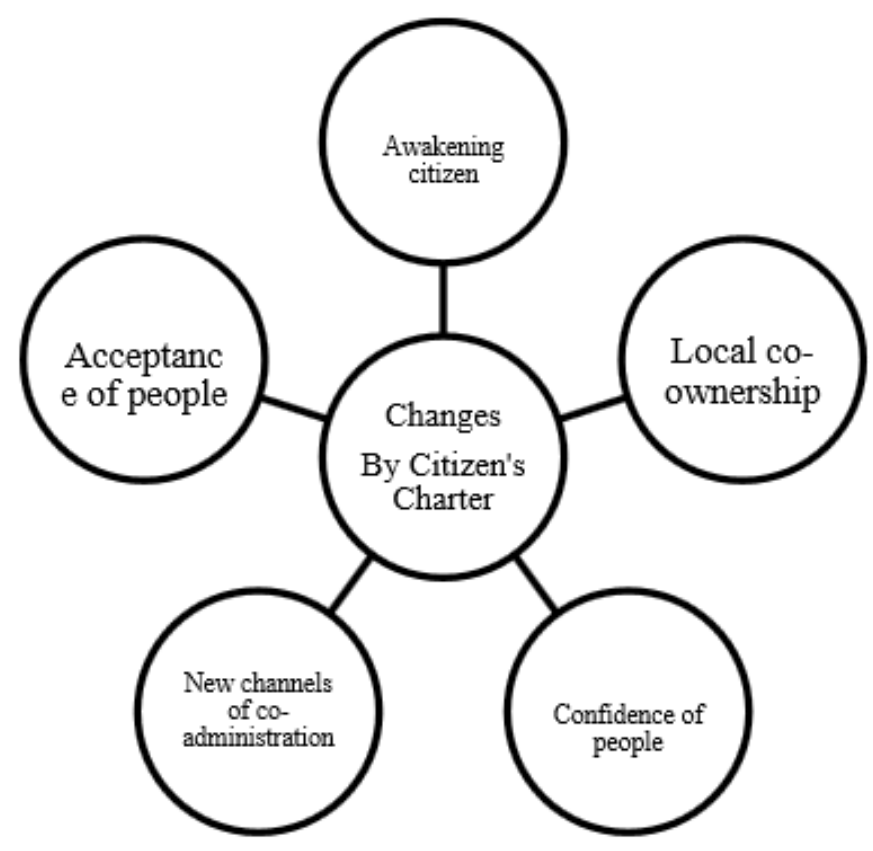




\section{DISCUSSION}

1. Partnership building, according to studies, it has been found that the citizen assembly is a tool to encourage people to participate in public administration in the manner of 'Partnership'. That means people would be fully integrated in to all the processes of local public policy and planning. Through the empowerment of the people, they have the opportunity to participate in the decision- making process of local development planning, together with the local government organization and other corporate groups in the area (Mandarano and Meenar. 2016; Avidar 2017). This has altered the attitudes, thinking, and practice of the local people radically. It aims to undo the attitude of people who have been convinced in the belief that they have no authority to make decisions regarding

2. problem solving of local government. However, this charter encourages people to be able to decide on a local solution in the same way as local government officials do. Citizens are an important part of the work in all areas of local administration, their needs are always recognized by the authorized officers. The focus on empowering people is the most important mission of the citizen's charter. It intends to change people or citizens from "those who need to be developed" as in the past, to be "those who can be the developer of their own community".As applied to the public, the citizen assembly is a tool that can give the people wider opportunities to join with government agencies in designing the province and local development in ways they find desirable. This is a process that bestows people with a sense of civic consciousness to join the government in determining their own future. This is a form of self-management to determine their provincial and local government in the future. The public will have the chance to play a role in shaping the goals of provincial and local government development in partnership. By this concept of citizen assembly, citizen engagement has genuinely been happened.

3. Ownership building, operating in this manner can increase the responsibilities of the people in developing their own local communities, especially in identifying the cause of a problem and its solution. This will develop learning of self-governance for the people also (Oyedemi 2015). It will strengthen the sense of ownership of the people. It was found that the importance of the participation of organizations, communities, and people with the local government focuses on creating a shared sense of ownership. It aims to push the process of creating real participation by encouraging people to share their thoughts and ideas (Skoric et al. 2015; Shark 2016). Co-ownership means that the people are involved in thinking about alternatives and discussions in making the 'right' decision. After having consulted and decided on the course of action, then it is a co-operative (Denhardt et al. 2015). If there are problems or obstacles in the operation, both public, private and people sectors need to work together to find solutions. The people have the right and the opportunities to work continuously with other sectors. These will establish coownership which develops a 'cherished' feeling to keep the local development process together (Druschke and Seltze 2015). The practices of promoting selfgovernance by the people will not be success unless ownership has not been 
Proceeding ICOGISS 2019

Page 9-26. ISBN: 978-602-6 988-75-1

Web Jurnal Online: jurnal.unmuhjember.ac.id

By: Sataporn Roengtam

Citizen Engagement And Local Governance Development

happened. Ownership creates a common understanding of community-based management. It can convince all sectors to agree and work together in achieving local development goals (Cornwall and Shankland 2015); .

4. Local self-governance, the citizen assembly tries to provide community organizations and individuals a way to work together with provincial government agencies. It aims to reconstruct the relationship between the two groups. It has designed a process to promote the role of the people and the original community organization, which have never previously been important in local administration (Acheampong and Dinye 2015; Galvez, Haro, and Caba 2017). Under the principle of the charter, collaborative dimensions are created. The aim is to change the relationship between people and the government agencies in a way that allows people to engage with government agencies to manage their own areas, known as "Co-Governance", as much as possible (Leao and Izadpahani 2016). For this important task, the citizen's charter is used for restructuring the relationship among government agencies and other sectors, including the people. This means that the public is a "common agreement" of these parties in the area. 


\section{CONCLUSION}

The results of the study above have all concluded that the citizen assembly is an important tool to strengthen the local people because it has the potential for increasing co-governance. It will be seen that people in the area strengthened their capabilities as it is used for promoting people's self- learning process in working with the local government through the process of developing local development plans and policies. This practice is a comprehensive learning process. The people who have joined this process can enhance their confidence, knowing that it is possible to work with local government organizations ( Davies, Selin, Gano, and Pereira. 2015; Kirlin and Kirlin 2014).

This is a significant change for the people involved, one that has never been seen before. People generally do not have belief but the use of the citizen assembly can empower them to work with local government. They are almost totally changed from believing that local administration is the responsibility of the state agency only and that people should not interfere or be involved. It should also be possible to limit their rights only if they are invited by the local government to participate in certain activities, such as being a contributor to comment and vote in the community forum held by the local government (Sharif 2015; T. L. Cooper et al. 2018)

The successful implementation of the citizen assembly is the outcome of cogovernance of local people. It helps increase the local people's feelings of "ownership" of the local community. This is a consequence of the learning process of the people as presented above. The ability of the people to work with the local government can build confidence. It has the effect of making people feel responsible for their own actions.

This is due to the fact that the people become responsible for implementing the development projects, so they have to take responsibility for their own community also (da Cruz, et al. 2016). When the people have more responsibility, this gives them a sense of community ownership as well (Teng et al. 2017; Warren, Sulaiman and Jaafar 2014). This is a major result of the citizen's charter in local governance. The sense of belonging to the local community is an important indicator that reflects the fact that people are ready to join the local government in a governance partnership.

Finally, from the results of citizen assembly, it can be concluded that it can bring the people and the community organizations working $\mathrm{s}$ with local organizations, closer. It can create new channels which are local development guidelines. These new channels are defined within the workflows and practices which can be important tools for empowering people to have greater self- governance (Iazzolino and Stremlau 2017; Hepburn 2015). So, after the adoption of the citizen assembly, it can be used to promote the co-governance of people in the area in two approaches. First, to be able to strengthen and change from being people to being citizens who are partners and coowners of local development with local government and other agencies. And second, it can open new channels for people to promote local and provincial self-governance. All of these are clearly discovered impacts of the citizen assembly 
Proceeding ICOGISS 2019

Page 9-26. ISBN: 978-602-6 988-75-1

Web Jurnal Online: jurnal.unmuhjember.ac.id

By: Sataporn Roengtam

Citizen Engagement And Local Governance Development

\section{References}

Acheampong, E.O. and Dinye, R.D., 2015, 'Women and Local Governance in

Developing Countries: A Case Study of Ejisu, Ghana', International Journal of

Public Administration 38(3), 200-215.

Avidar, R., 2017, 'Public Relations and Social Businesses: The Importance of Enhancing

Engagement', Public Relations Review 43(5), 955-62.

Cheshire, L., Everingham, J. and Lawrence, G., 2014, 'Governing the Impacts of

Mining and the Impacts of Mining Governance: Challenges for Rural and Regional

Local Governments in Australia', Journal of Rural Studies 36, 330-39.

Chong, J., et al., 2016, 'Strengthening Local Governance Arrangements for Sanitation:

Case Studies of Small Cities in Indonesia', Aquatic Procedia 6, 64-73.

Cobo, C., 2016, 'Networks for Citizen Consultation and Citizen Sourcing of Expertise', Contemporary Social Science 7(3), 283-304.

Cook, N.J., Wright G.D. and Andersson, K.P., 2017, 'Local Politics of

Forest Governance: Why NGO Support Can Reduce Local

Government Responsiveness', World Development 92, 203-14.

Cornwall, A. and Shankland, A., 2015, 'Cultures of Politics, Spaces of Power:

Contextualizing

Brazilian Experiences of Participation', Journal of Political Power 6(2), 309-33.

Cruz, N.F. and Marques, R.C., 2017, 'Structuring Composite Local Governance Indicators',

Policy Studies 38(2), 109-129.

D'Ambrosi, L., 2017, 'The Global Active Citizenship Network in Italian Local Contexts: Using Social Media to Promote Sustainable Behaviours', Javnost 24(1), 34-48.

Denhardt, J., Terry, L., Delacruz, E.R. and Andonoska, L., 2015, 'Barriers to Citizen Engagement in Developing Countries', International Journal of Public Administration 32(14), 1268-88.

da Cruz, N.F., et al., 2016, 'Measuring Local Government Transparency', Public Management Review

18(6), 866-93.

Davies, S.R., Selin, C., Gano, G. and Pereira, A.G., 2015, 'Citizen Engagement and Urban Change: Three Case Studies of Material Deliberation', Cities 29(6), 351-57.

Dobos, A. and Jenei, A., 2015, 'Citizen Engagement as a Learning Experience', Procedia - Social and Behavioral Sciences 93, 1085-89.

Eom, S.J., Hanchan H. and Kim, J.H., 2018, 'Can Social Media Increase Government Responsiveness? A Case Study of Seoul, Korea, Government Information Quarterly 35(1),1-14.

Druschke, C.G. and Seltze, C.E., 2015, 'Failures of Engagement: Lessons Learned from a Citizen 
Proceeding ICOGISS 2019

Page 9-26. ISBN: 978-602-6 988-75-1

Web Jurnal Online: jurnal.unmuhjember.ac.id

By: Sataporn Roengtam

Citizen Engagement And Local Governance Development

Science Pilot Study', Applied Environmental Education and Communication 11(3-4), 78-188. Galvez, R.M.M., de Rosario, A.H. and Caba, C., 2017, 'Improving Citizens ' Online Engagement via

Community Managers: An Explanatory Study Managers: An Explanatory

Study', Information, Comunication and Society 21, 1-17.

Gaventa, J. and Barrett, G. 2012, 'Mapping the Outcomes of Citizen Engagement', 40(12), 2399-2410.

Goetz, A.M. and Jenkins, R., 2015, 'Hybrid Forms Of Accountability : Citizen

Engagement in Institutions of Public-Sector Oversight in India Citizen

Engagement in India', Public Management Review 3(3), 363-383.

Hepburn, P., 2015, 'Local Governance and the Online Networked Public Sphere-A Case Study',

Journal of Information Technology and Politics 9(4), 370-87.

Hoffken, S. and Streich, B., 2015, 'Mobile Participation: Citizen Engagement in Urban

Planning via Smartphones', Citizen E-Participation in Urban

Governance, 199-225. Hokayem, J.E. and Kairouz, A., 2015, 'Euro-Med:

Public Management and Good Local

Governance', Procedia - Social and Behavioral Sciences 124, 528-35.

Hong, K.J., Keane, T.D. and Bernard, E.A., 2015, 'Fragmented Local Governance and Water

Resource Management Outcomes', Journal of Environmental Management

150, 378-86. Kirlin, J.J. and Kirlin, M.K., 2014, 'Strengthening Effective

Government-Citizen Connections

through Greater Civic Engagement', Public Administration Review 62(4), 80-85.

Korthagen, I. and Meerkerk, I.V., 2015, 'The Effects of Media and Their Logic

on Legitimacy Sources within Local Governance Networks: A Three-

Case Comparative Study', Local Government Studies 40(5), 705-28.

O'Byrne, S. and Daymon, C., 2015, 'Irresponsible Engagement and the Citizen Investor', Journal of

Public Relations Research 26(5), 455-473.

Iazzolino, G. and Stremlau, N., 2017, 'New Media and Governance in Conflict', Third World

Quarterly 38(10), 2242-57.

Leao, S. and Izadpahani, P., 2016, 'Factors Motivating Citizen Engagement in

Mobile Sensing: Insights from a Survey of Non-Participants', Journal of

Urban Technology 23(4), 85-103.

Mandarano, L. and Meenar, M. 2016, 'Building Social Capital in the Digital Age of Civic

Engagement', Journal of Planning Literature 25(2), 123-135.

Mazali, T., 2017, 'Social Media as a New Public Sphere Linked',

Meijer, A., van der Veer, R., Faber, A. and de Vries, J.P., 2017, 'Political Innovation as Ideal and

Strategy: The Case of Aleatoric Democracy in the City of Utrecht', Public Management Review 
Proceeding ICOGISS 2019

Page 9-26. ISBN: 978-602-6 988-75-1

Web Jurnal Online: jurnal.unmuhjember.ac.id

By: Sataporn Roengtam

Citizen Engagement And Local Governance Development

Men, L.R. and Tsai, W.H.S., 2016, 'Public Engagement with CEOs on Social Media:

Motivations and

Relational Outcomes', Public Relations Review 42(5), 932-942.

Morris-Suzuki, T. and JEONG, S. E., 2015, New Worlds from Below: Informal

life politics and grassroots action in twenty-first-century Northeast Asia,

249-274.

O'Byrne, S. and Daymon, C., 2015, 'Irresponsible Engagement and the Citizen Investor', Journal of

Public Relations Research 26(5). 455-473.

Oyedemi, T., 2015, 'Internet Access as Citizen's Right? Citizenship in the Digital Age', Citizenship

Studies 19(3-4), 450-464.

Panagiotopoulos, P., Bigdeli, A.Z. and Sams, S., 2014, 'Citizen-Government Collaboration on Social

Media: The Case of Twitter in the 2011 Riots in England', Government Information Quarterly

31(3): 349-357.

Reforgiato, R.D., et al., 2016, 'An Innovative, Open, Cloud, Interoperable ICT Platform for Smart

Government and Interaction with Citizens', Journal of the Knowledge Economy

7(2), 388-412. Roberts, N., 2014, 'Public Deliberation in an Age of Direct Citizen

Participation', American Review

of Public Administration 34(4), 315-353.

Sharif, M.H.M., 2015, 'Public Sector Adoption of Social Media', Journal of Computer Information Systems 55(4), 53-61.

Shark, A.R., 2016, 'The Information Technology Gap in Public Administration: What We Can Learn From the Certified Public Manager and Senior Executive Service Programs', Journal of Public Affairs Education 22(2), 213-30.

Skoric, M.M., Zhu, Q., Goh, D. and Pang, N.L.S., 2015, 'Social Media and Citizen Engagement: A Meta- Analytic Review', New Media \& Society 18(9), 18171839.

Taylor, M. and Kent, M.L, 2014, 'Dialogic Engagement: Clarifying Foundational Concepts.',Journal of Public Relations Research 26(5), 384-398.

Teng, C.M., et al., 2017, 'Transformation in Philippine Local Government', Local Government Studies 43(1), 64-88.

Unceta, A., Castro-spila, J. and Fronti, J.G., 2017, 'The Three Governances in Social Innovation', Innovation: The European Journal of Social Science Research 30(4), 406-420.

Virtudes, A., 2016, 'Good' Governance Principals in Spatial Planning at Local Scale.', Procedia

Engineering 161, 1710-14.

Warren, A.M., Sulaiman, A. and Jaafar, N.I., 2014, 'Social Media Effects on Fostering Online Civic Engagement and Building Citizen Trust and Trust in 
Proceeding ICOGISS 2019

Page 9-26. ISBN: 978-602-6 988-75-1

Web Jurnal Online: jurnal.unmuhjember.ac.id

By: Sataporn Roengtam

Citizen Engagement And Local Governance Development

Institutions', Government Information Quarterly 31(2), 291-301.

Wijnhoven' M.F., and Kuhn, E.J. 'Open government objectives and participation motivations'

Government Information Quarterly 32(1), 30-42.

Yin, Y., Olsson, A.R. and Hakansson, M., 2016, 'The Role of Local

Governance and Environmental Policy Integration in Swedish and

Chinese Eco-City Development.', Journal of Cleaner Production

$134,78-86$.

Zavattaro, S.M. and Sementelli, A.J., 2015, 'A Critical Examination of

Social Media Adoption in Government: Introducing

Omnipresence', Government Information Quarterly 31(2), 257-

264.19(1), 20-36. 